\title{
Neurological disorder and psychosocial aspects of cerebral malaria: what is new on its pathogenesis and complications? A minireview.
}

\author{
Arif Jamal Siddiqui ${ }^{1 \|^{*}}$, Mohd Adnan ${ }^{1 \#}$, Sadaf Jahan ${ }^{2}$, Whitni Redman ${ }^{3}$, Mohd Saeed ${ }^{1}$, Mitesh Patel ${ }^{4}$ \\ \# Both authors have contributed equally and should be considered as first authors, \\ ${ }^{1}$ Department of Biology, College of Science, University of Hail, Hail, PO Box 2440, Saudi Arabia; \\ ${ }^{2}$ Department of Medical Laboratory, College of Applied Medical Sciences, Majmaah University, Majmaah city, Saudi Arabia; \\ ${ }^{3}$ Surgery Department, Division of Biomedical Research, Texas Tech University Health Sciences Center, Lubbock, Texas, USA; \\ ${ }^{4}$ Bapalal Vaidya Botanical Research Centre, Department of Biosciences, Veer Narmad South Gujarat University, Surat, Gujarat, India
}

\begin{abstract}
Recently, malaria is remain considered as the most prevalent infectious disease, affecting the human health globally. High morbidity and mortality worldwide is often allied with cerebral malaria (CM) based disorders of the central nervous system, especially across many tropical and sub-tropical regions. These disorders are characterised by the infection of Plasmodium species, which leads to acute or chronic neurological disorders, even after having active/effective antimalarial drugs. Furthermore, even during the treatment, individual remain sensitive for neurological impairments in the form of decrease blood flow and vascular obstruction in brain including many more other changes. This review briefly explains and update on the epidemiology, burden of disease, pathogenesis and role of $\mathrm{CM}$ in neurological disorders with behaviour and function in mouse and human models. Moreover, the social stigma, which plays an important role in neurological disorders and a factor for assessing CM, is also discussed in this review.
\end{abstract}

Key words: Antimalarial, Plasmodium, neuropathology, iRBC, cognitive disability

Despite the advances in medical science, malaria remains a fatal disease with a global health impact, affecting the lives of 3.3 billion people worldwide. Between 2016 and 2018, approximately 400 million cases were reported with nearly 900,000 deaths (WHO 2017, 2018). Most of the malaria cases were reported from sub-Sahara African region amongst pregnant women and children of age 5 and below. Plasmodium falciparum Welch, 1897, a known causative agent of neurological impairments in humans is also recurrently considered as utmost vital in rapport of deaths. According to WHO, health threat to humans is significantly reported by five main species of Plasmodium (P. falciparum, Plasmodium malariae Grassi et Feletti, 1890, Plasmodium ovale Stephens, 1922, Plasmodium knowlesi Franchini, 1927 and Plasmodium vivax [Grassi et Feletti, 1890]) (WHO 2015).

Other Plasmodium subspecies like P. ovale, P. ovale curtisi Sutherland et al., 2010 and P. ovale wallikeri Sutherland et al., 2010 are rare to cause noteworthy diseases and no significant and definite evidence is known in regards to its primary transmission between humans to humans rather than animal to humans (Ahmed and Cox-Singh 2015). Historically, $P$. falciparum possibly applied bigger selective evidence in human evolution in comparison to other kind of pathogens. Despite the presence of $P$. falciparum all over the tropical region causing malaria, its impact on health is much more disastrous by causing multiple neurological disorders in later stages after treatment. Though, huge sect of population is parasitised worldwide, but ratio of death in Africa is touching almost $90 \%$ comparatively, especially children and women (WHO 2015).

Female of Anopheles Meigen, 1818 mosquitoes transmit the malaria parasite via injecting sporozoites during sucking a blood meal (Crompton et al. 2014, Ahmed and Cox-Singh 2015, Bhardwaj et al. 2016, Thievent et al. 2019) The sporozoites reach to the liver through blood stream and enter into hepatocytes, where they grow exponentially and finally into mature schizonts. Later, the mature hepatic schizonts got erupted and discharge the countless merozoites, which further reaches the erythrocytes. Asexual cycle was then initiated by merozoites within 24 hours for P. knowlesi, 48 hours for $P$. vivax, $P$. ovale and $P$. falciparum and 72 hours for P. malariae (Kerlin and Gatton 2013, Bhardwaj et al. 2015, Thievent et al. 2019). After complete development of erythrocytic schizont cycles, they rupture and releases mero- 
zoites into the blood stream and infect the red blood cells (RBCs) and further repeat the cycle of infection. Not all, but some merozoites grow into gametocytes and spread malaria by vector after taking blood meal from the host. (Siddiqui et al. 2011, Crompton et al. 2014, Soni et al. 2015). Usually, the pre-erythrocytic condition is asymptomatic and symptoms only occur, when parasitic cycle of malaria is completed in the blood (Prudencio et al. 2006, White et al. 2013, Siddiqui et al. 2015, Thievent et al. 2019).

Clinical assurance of malaria varies from asymptomatic to symptomatic, and is mostly dependent on the individual's immune system and infection capacity of species of Plasmodium. Host immune strength is determined by the age of individual, prior parasite exposure, and degree of virulence of the parasite in the environment. Comparatively, mostly pregnant females and children are at larger risk than others in developing this severe/fatal disease (Baird et al. 1998, Schantz-Dunn and Nour 2009, Schumacher and Spinelli 2012, Siddiqui et al. 2018). In the endemic area, individuals with strong immunity mostly tolerate the asymptomatic malaria. In contrast, patients with less immunity suffer from symptomatic malaria with symptoms including fever, chills, headache and vomiting. Patients with $P$. falciparum infection from additional difficulties like severe anemia, acidosis and respiratory associated complications. In adults, multi-organ failure is also frequently reported (Newton and Krishna 1998, Dondorp et al. 2008a, Perkins et al. 2011, Prakash et al. 2014, Thievent et al. 2019)

\section{Epidemiology, burden and transmission of malaria}

Malaria is spread approximately in more than 90 countries (Win Han et al. 2019), with a leading cause of mortality and morbidity in endemic areas. About $96 \%$ of approximately half million patients in sub-Saharan Africa died from $P$. falciparum associated malaria, mostly women and children below 5 years (WHO 2018). The key factors responsible for transmission are ecological factors, especially temperature, which a mosquito can sustain and ultimately support the parasite development in it (Dollat et al. 2019, Win Han et al. 2019). Besides this, the level of transmission is set by recurrence of interaction between humans and infected mosquitoes including their population density, feeding habits and suitable habitats (Stresman et al. 2019). Due to multifactorial contributing conditions, the level of transmission is complicated and does not provide the convincing picture of the disease in exposed communities with parasitemia (usually asymptomatic) (Chitnis et al. 2019).

Malaria is considered to be unstable, where threat of infected mosquito bites is low. However, in stable endemic areas, disease severity and death are limited mostly to youngsters, while adults develop a degree of immunity due to rise in exposure times (Apinjoh et al. 2019, Chitnis et al. 2019). Under moderate-to-low transmission settings, $\mathrm{CM}$ is reported to be more prevailing and all age groups are prone to infection. Ultimately, spreading of infection occurs slowly, year by year, leading towards other clinical and neurological stigmatic disorders (Dayananda et al. 2018, Reiner et al. 2019). It has been suggested that high number of indirect mortality (cause of death other than malaria) is linked to malaria exposure. This fact was supported by many epidemiological studies (Scott et al. 2011, Cowman et al. 2016, Reiner et al. 2019).

\section{Cerebral malaria}

$\mathrm{CM}$ is provoked by $P$. falciparum, causing severe neurological impairment during infection. This parasite is associated with diffuse encephalopathy including coma and is accountable for millions of death globally. According to WHO, CM is type of known clinical syndrome described by coma, hypoglycemia and presence of parasite's asexual form in connective tissues (Who 2015). In spite of having all precautions and effectual antiparasitic therapy, CM causes approximately $15-22 \%$ mortality. If somehow patients survive, they develop long-standing neurological problems (Carter et al. 2006, Boivin et al. 2007, John et al. 2008, Postels and Birbeck 2013, Brejt and Golightly 2019). Swift spreading of malarial parasite is very common in Africa and it predominantly happens in kids (5 years and younger). Adults are rarely susceptible to intense form of transmission.

Noticeably, cause of death by malaria in other parts of the world is lower, especially in South East Asia and South America. However, its later effects are significant and exhaustive for an individual. The clinical indications of CM vary among adults and children (Newton and Krishna 1998, Hawkes et al. 2013, Wassmer et al. 2015, Bruneel 2019), which signifies the involvement of different pathophysiological characters linked with human cerebral malaria (HCM). It is also reported that adults suffer from CM confronts another acute problems like multi-organ failure, kidney failure, dysfunctioning of liver, respiratory disorders and finally central nervous system (CNS) impairment. However, when CM is related to African kids coma, anemic conditions and seizures were found to be more associated than renal and respiratory system failure (Marsh et al. 1995, Idro et al. 2005, Brejt and Golightly 2019). CM is also allied with retinal abnormalities and symptoms of retinopathy. Therefore, it is used as a tool to distinguish malarial coma from non-malarial coma (Beare et al. 2004, 2006, 2011, Taylor et al. 2004, Lewallen et al. 2008, Wijdicks and Park 2018).

\section{Cerebral malaria in rodent model}

Experimental cerebral malaria (ECM) model with Plasmodium berghei Vincke et Zips, 1948 ANKA (PbA)-induced infection has been broadly studied to evaluate the mechanisms involved for the onset of CM in mice. In this model, when a susceptible mouse is infected with $\mathrm{PbA}$, it dies within 2 weeks of infection showing various neurological symptoms and signs (convulsion, ataxia, paralysis, coma, etc.) (Engwerda et al. 2005, Brejt and Golightly 2019). Couple of studies demonstrated that demonstrated that accumulation of infected red blood cells (iRBC) in the brain of mice is crucial for the advancement of ECM (Baptista et al. 2010, Brejt and Golightly 2019). While, other studies have explained that $\mathrm{PbA}$ iRBC can gather in murine brain including other organs (Hearn et al. 2000, Franke-Fayard et al. 2005). However, sequestration of $\mathrm{iRBC}$ in the brain vasculature is not a key histopathology feature in murine CM and its relation with ECM was not illustrated (Hearn et al. 2000, 
Franke-Fayard et al. 2005). Many other studies reported the relation of $\mathrm{iRBC}$ sequestration with the onset of ECM in different organs, including brain, using luciferase-expressing $\mathrm{PbA}$. As mice started developing clinical symptoms, dense amount of parasites in different organs of infected mice was found (Amante et al. 2010, Claser et al. 2011). As mice started developing clinical symptoms, they found dense amount of parasites in different organs of infected mice. Recently, a specific feature of ECM has been demonstrated, i.e. accrual of iRBCs in brain blood vessels by $\mathrm{PbA}$ and not by P. berghei NK65 infection (Strangward et al. 2017). This development is an additional contributing characteristic in the pathogenesis of ECM, proving that single $\mathrm{iRBC}$ is enough to blockade of a brain capillary in PbA-infected mice, which parallels human CM. The ECM model also shows few similarities to P. falciparum human cerebral malaria (HCM) (Hunt et al. 2010, Ghazanfari et al. 2018).

\section{Complexity of pathogenesis}

Host inflammatory responses, micro-vascular obstruction and proliferated parasite development are few crucial and necessary points in $P$. falciparum-induced infection, which promotes its pathogenesis leading to illness and death. This is because mature parasites are capable to adhere the endothelial cell lining blood vessels (Wassmer et al. 2015). Adherence (sequestration) plays a significant role in parasite pathogenesis and triggers an acute inflammatory response. Severe malaria is a result of side effects of inadequately controlled inflammatory responses to control the initial stage of malarial infection (Cunnington et al. 2013). The foremost method accountable for HCM development and a sign for $\mathrm{CM}$ in adults and children is sequestration of iRBC in human brain, infected with P. falciparum (see Macpherson et al. 1985, Silamut et al. 1999, Pongponratn et al. 2003, Ghazanfari et al. 2018). Translocation of mature parasites present in iRBCs takes place from peripheral circulation to micro-vessels of different organs and brain.

A particular cell-surface ligand, which is expressed by iRBCs called as erythrocyte membrane protein-1 (PfEMP-1) of $P$. falciparum is responsible for iRBCs adhesion to vascular endothelium. On the endothelial cells (i.e., intercellular adhesion molecule 1 (ICAM-1), CD36 and endothelial protein $\mathrm{C}$ receptor (EPCR), PfEMP-1 is capable for binding with many host ligands (Newbold et al. 1997, Craig and Scherf 2001, Chakravorty and Craig 2005, Kraemer and Smith 2006, Ghazanfari et al. 2018). Numerous findings have proven the correlation between CM coma patients and sequestration of iRBCs in cerebral vessels (Macpherson et al. 1985, Pongponratn et al. 1991, Silamut et al. 1999, Pongponratn et al. 2003, Ponsford et al. 2011). Shortage of oxygen, fall in blood flow and coma, are known factors of iRBCs accumulation in cerebral capillaries, causing unconscious obstruction of the vessels, further leading to death (Macpherson et al. 1985, Brejt and Golightly 2019).

Some patients were mistakenly diagnosed, as sequestration of iRBCs was not found in their brain. Therefore, it is not right to say that finding sequestration of iRBCs in the brain capillaries is the cause for CM (Taylor et al. 2004, Ghazanfari et al. 2018). This shows the complexity of pathogenesis in CM. Many factors play a significant role in pathogenesis of $\mathrm{CM}$, resulted in common side effects, which are not restricted to just cerebral/brain tissues only (Luzolo and Ngoyi 2019). However, abnormalities of endothelial and $\mathrm{iRBC}$ sequestration have been determined in different organs (lung, kidney, skin, heart and intestine). Together, the leakage in the perivascular space is an outcome from the various defined pathological mechanisms, which could ultimately disturb the auxiliary cells (astrocytes and pericytes) prominent to localised breakdown of the BBB (Luzolo and Ngoyi 2019).

\section{Microvascular destruction and activation of endothelial cells}

The most important attribute of $P$. falciparum in causing severe malaria is associated with sequestration of mature parasites in micro-vascular beds, followed by obstruction of blood flow in tissues, which contributes in organ damage, acidosis and change in brain metabolic activities (Autino et al. 2012, Ghazanfari et al. 2018). This contribution to sudden effects like organ damage, acidosis and change in brain metabolic activities. Reduced blood flow and sequestration are directly interconnected and quantified in various tissue masses of retina and mucosal surface of rectum on many occasions (Bruneel 2019). The histological feature with other clinical signs acts as a prognostic marker like acidosis and neuronal activity (Dondorp et al. 2008b). Large number of proteins are able to bind and interact with cell receptors of endothelial cells, activated platelets and uninfected erythrocytes, leading to formation of clumps of infected cells (Brejt and Golightly 2019). The process of binding to uninfected erythrocytes is called resetting, and together with sequestration, this combined process is majorly responsible for the severity of disease (Brejt and Golightly 2019).

Activation of endothelial cells plays a foremost role in micro-vascular pathology of $P$. falciparum. Increase in the expression of receptors takes place soon after the endothelial cells get activated (Bruneel 2019). This resulted in binding infected erythrocytes to those receptors. Scientists have recently answered a long-term unanswered question, i.e., why brain is inclined towards the sequestration consequences and how cell adherence directs the endothelial dysfunction (Brejt and Golightly 2019). Answer and probable elucidation is the binding of newly identified endothelial protein $\mathrm{C}$ receptor (EPCR) as a ligand for PfEMP1-mediated infected erythrocyte (Bruneel 2019). In fact, this acts as marker and imparts a specific role on the result. EPCR has a key function in stabilising endothelial cells by stimulating protein $\mathrm{C}$ initiation. It expresses more in micro-vascular beds. A bleeding disorder, coagulopathy, is a result of infected $\mathrm{RBC}$ to EPCR coupling by hindering the protein $\mathrm{C}$ activation (Turner et al. 2013). Later, it was found out that impairment of blood's ability to coagulate predominantly happens in brain due to lower expression of thrombomodulin (TM) and EPCR (Moxon et al. 2013). Relation of severe malaria with the ways of PfEMP1 binding with EPCR is proportional. Thereby, EPCR provides a possible and substantial linkage amid host factors arbitrating between severity of the host and parasite (Turner et al. 2013). 


\section{Neuropathology of cerebral malaria}

Approximately $27 \%$ of juvenile cases ended with severe brain injuries including epilepsy and other long-term cerebral disorders after CM (Carter et al. 2005a, Ngoungou et al. 2006, John et al. 2008, Brejt and Golightly 2019). Depending on time and inception of symptoms, CM is characterised by two models of neurological disorder outcome (Idro et al. 2010a). The first model is instant symptoms; which resulted in status epilepticus (SE), followed by coma in CM patients. Other effects may also emerge like hemiplegia, spastic quad cerebral palsy, multifocal seizures, cognitive and motor disorders, impairment of sense; (behaviour, hearing and speech) depends on the severity of illness (Bruneel 2019). The second model is time linked: symptoms like epilepsy and behavioral defalcation start appearing within few months to years after the onset of CM (Bruneel 2019).

Together with all motor disorders, movement disorders like gait, ataxia, choreoathetosis, poor neck control and dystonia can be used to determine and distinguish the complexity and severity of the disease (Daroff 2001, Bruneel 2019). In a murine model of cerebral malaria, unregulated signalling of GSK3 $\beta$ and Akt is directly associated with motor disorders (Dai et al. 2012). Suppression of GSK3 $\beta$ and Akt pathways progressed in alterations of neuronal veracity. Moreover, protein kinase has a significant role in apoptosis regulation, various signalling pathways and cell viability via regulating the biological activities of proteins (Patel et al. 2019). Likewise, other neurological disorders may contribute to some sort of cerebral trauma, for example; intracranial hypertension, where death does not occur. However, shortening of oxygen, nutrients and perfusion pressure in brain causes ischemia leading to brain tissue atrophy (Newton et al. 1997, Frevert and Nacer 2014).

Aggravating products like quinolinic acid, which triggers the neuro-inflammation, are commonly responsible for seizures in CM leading to cell death by affecting the excitatory neurotransmitters (Stone et al. 1987, Heyes et al. 1993, Nakamura et al. 1995, Idro et al. 2010b). Due to this excitatory effect on neurons after seizures, the damage is irreversible and triggers long-term harmful cognitive and behavioural effects (Sokol et al. 2003). Due to ischemic injury and hypoxia, reoccurrence of epilepsy takes place without any cause and a normal brain is functionally altered. This process is called as epileptogenesis, whose actual mechanism is still not known (Walker et al. 1992, Crawley et al. 1996, Idro et al. 2010b, Ssentongo et al. 2017).

Many other aspects may add the part to cause epileptogenesis, which may include formation of malarial granulomas, genetic tendency and structural brain damage (Aleem 2005, Ssentongo et al. 2017). It was found that children surviving from acute malaria in Kenya are mostly neurocognitive impaired (i.e., speech and hearing) (Carter et al. 2005b). Many other studies reported and uncover the effects of CM on children, which include spatial illusion, impairment in visual memory, hand dominance, auditory processing, regulation of skills (mental, social and learning), attention deficit and other neurological based processing problems (Dugbartey et al. 1998, Burkey et al. 2015). The anomalous hyper phosphorylation of tau protein is also one of the most important characteristics of other neurodegenerative disorders and a noteworthy factor in the onset of Alzheimer's disease and other tauopathies (Iqbal et al. 2005, Wang and Liu 2008).

$\mathrm{CM}$ survivors have to face long-lasting lack of cognitive processing, regulation, hyperactivity, spontaneity, absent-mindedness and other areas of mental disorders due to abnormal levels of tau in their cerebral spinal fluid or specific injury in neuronal areas (Holding et al. 1999, Boivin et al. 2007, Idro et al. 2016). This is all similar to attention deficit hyperactivity disorder (ADHD) (Singh et al. 2016), which is linked with CM survivors. Neuronal loss and reduction in blood flow in brain creates disability in dopamine signals and as a result ADHD (Lou et al. 1989, Shikani et al. 2012). Linkage between ADHD and $\mathrm{CM}$ has been shown in a CM-infected murine model. Similar associated symptoms and presence of hemorrhage have demonstrated that, later stages of CM can cause parenchymal hemorrhage and increases the severity of disease (Lackner et al. 2006). Similarly, another murine model with experimental CM induced by P. berghei was tested for cytokine response in brain and showed the inflammatory and neurological changes (Lacerda-Queiroz et al. 2010, Bakmiwewa et al. 2015, Apoorv and Babu 2016). Uniquely, another study supported the theory of cytokine response and relation with psychotic disorders. This experiments has demonstrated the nervousness like behaviour in C57BL/6 mice, which was infected with $P$. berghei. The symptoms were correlated with pathological and histological disparities in cerebrum, hippocampus and brain stem. Additionally, with higher levels of chemokines and TNF- $\alpha$ (De Miranda et al. 2011, Zhang et al. 2018a,b).

Another important key factor in the neuropathogenesis of CM is glutamate levels. It is the most abundant neurotransmitter present in our brain and CNS. It has been reported that glutamate levels and neurological disabilities are interconnected (Miranda et al. 2010, De Miranda et al. 2016). The presence of higher amount of glutamate levels in cerebrospinal fluid of experimental models trigger neuronal cell death, neurotoxicity and is connected with changes in cognitive behaviour, reflex and sensory functions and various other physiological neuropsychiatric conditions (Meldrum 2000, Medana et al. 2009, Oliveira et al. 2017). This establishes the possible mechanism for neuropathogenesis in $\mathrm{CM}$, and after two months of severe $\mathrm{CM}$, patient starts developing neuropsychiatric symptoms (Miranda et al. 2010). After two months of severe CM, individual started developing neuropsychiatric symptoms. Medically, it is called as post malaria neurological syndrome (PMNS), which is an acute confused state of mind stage. Symptoms include visual and auditory hallucinations, incapability to communicate, etc. (Nguyen et al. 1996, Wilson et al. 2016).

\section{Cerebral malaria and social stigma}

The real complications soon occurs after the CM infection, which brings the societal changes in patient lives and equally affects the close community members. This is specifically due to the neurological symptoms of post cerebral 
malaria infection like behaviour complications (Idro et al. 2010b), which includes recklessness, hyperactivity, negligence, attention deficit hyperactivity disorder (ADHD), aggressiveness, vicious behaviour etc. (Mbale et al. 2017). These symptoms somehow directly or indirectly target the community and put them to risk (Jones and Williams 2004). Other complications which impart or contribute in affecting the society are weakness in spastic motor, speech loss (Mbale et al. 2017), behaviour complications (Idro et al. 2010b), hearing issues (Mbale et al. 2017), impaired vision (Idro et al. 2006), epilepsy and other severe cognitive disorders (Idro et al. 2006). There is always a considerable social pressure on patient and patient's close family members in taking various treatment decisions. Due to this pressure, patient's condition get worsen including effect on their care-giver, who sometimes may lose control over the decision-making process (Mbale et al. 2017).

Most reports and studies have only revealed the problems associated to functional impairments, without giving attention to community involvement, schooling, socialisation, etc. The impact of CM goes beyond the individual to the wider effect on the family, which is influenced by the surrounding environment and social stigma (Who 2018). Cognitive impairment is a type of disability, which leaves a huge impact on individual and families in their social life (Alavi et al. 2012). Some ailments such as epilepsy/seizures are often associated with witchcraft considered contagious, even further and cause stigma and discrimination for the family (Nelson et al. 2017). Scientific literature is full of outcomes related to neurological functioning and impairment of CM, but social inferences of having a child with a cognitive disability have never been effectively considered in outcome studies and need to be explored in detail.

\section{Advancement of chemotherapy and molecular mechanism}

Chemotherapy, as a first treatment, still plays a vital role in treating cerebral malaria. Antimalarial drugs are the agents used to inhibit the development of malaria parasites (Azad et al. 2017). They are administered with the aim of totally eradicating the parasites and have selective action on different phase's of the parasite life cycle. Infected patients when treated with antimalarial drugs face many challenges counting partial effectiveness, drug side effects and drugs resistance (Sahu et al. 2015, Riggle et al. 2020). Therefore, new and effective antimalarial drugs with novel mechanism of actions are immediately necessary. However, since last decade, researchers have been devising novel ways to reduce the uptake and concentration of chemotherapy. This improvement upon existing antimalarial drugs can only happen by adding/deleting or chemically modifying the compounds. Furthermore, presence of advance molecular methods, genomics tools and modern technological approaches like structure based drug designing and new ways of searching treatment can improve the effectiveness of drugs with lower/none side effects as well as combating drug resistance (Samby et al. 2019). There are many approaches which are currently under trial/developing for the identification of novel drug targets and chemical entities
(Nishanth and Schluter 2019). Some of the novel drug targets for future are discussed here in brief.

Several drugs, targeting the membrane biosynthesis of parasite have already been identified by various research groups (Ancelin et al. 2003, Wells et al. 2015). They observed that, during malarial infection, parasite requires large amount of phospholipids and need to synthesise the cell membrane during separation, growing and while dividing. Because of their observation, they discovered one of the most leading and novel antimalarial drug, i.e., G25. G25 compound inhibits the plasmodium development in both experimental process such as in vitro and in vivo (Roggero et al. 2004). Similarly, dinucleoside dimer (Chatterjee and Yeung 2012) and hexose derivative (Crabb et al. 2012) compounds are also leading compounds which involve disrupting the mechanism of phospholipid synthesis membrane transports system in parasite.

Furthermore, other compounds thiolactomycin (Dechy-Cabaret and Benoit-Vical 2012), triclosan (Deweerdt 2012), fosmidomycin (Eisenstein 2012) and peptidomimetics (Yadav et al. 2019) are also being under investigation as a possible apicoplast drug target during fatty acid synthesis. Moreover, new quinolines (Wells et al. 2015, Yadav et al. 2019), protease inhibitors (Bushell et al. 2017) and new peroxides (Hien et al. 2017) are also novel drugs target during parasite food vacuole formation (Yadav et al. 2019). Some new drugs have been identified to inhibit the growth of parasite during the cytosol formation, and they are Gossypol derivates (Yadav et al. 2019), 5-fluoroorotate (Shetty 2012), chlorproguanil (WHO 2017, Yadav et al. 2019), actinonin (WHO 2011), geldanamycin (WHO 2006).

Other novel compounds are involved in inhibiting the pathway or mechanism of folate metabolism, glycolysis, protein synthesis, glutathione metabolism and other parasitic pathways (Yadav et al. 2019). Phase II clinical trials of few leading drugs and their combinations are completed recently, such as methylene blue with primaquine (Tse et al. 2019) and fosmidomycin with piperaquine. Some drugs are formulated as triple combination that is imatinib with dihydroartemisinin-poperaquine, which is going in phase II clinical trial (Samby et al. 2019, Tse et al. 2019). Furthermore, there are many other novel and promising anti-malarial drugs, which are currently in pre-clinical stage. Some of them are NPC1161B (Marcsisin et al. 2014), MK4815 (Powles et al. 2012), CDRI97/78 (Shafiq et al. 2014, Tse et al. 2019), Artemisone (Haynes et al. 2006), AQ-13 (Tse et al. 2019), M5717 (Baragana et al. 2015), MMV253 (Hameed et al. 2015), UCT943, AN13762, AN3661, SC83288, DM1157 (Burgess et al. 2010), P218 (Yuthavong et al. 2012), SJ733, ACT451840, OZ277 (Vennerstrom et al. 2004), OZ439, KAF156, DSM265 (Coteron et al. 2011). The possible mode of action of all these leading and novel drug compounds belong to translational elongation factor 2 (PfeEF2) inhibitor, V-type H+-ATPase inhibitor (Tse et al. 2019), phosphatidylinositol 4-kinase (PfPI4K) inhibitor, dihydroorotate dehydrogenase (PfDHODH) inhibitor, P-type Na+-ATPase inhibitor (PfATP4) and dihydrofolate reductase (PfDHFR) inhibitor, respectively (Tse et al. 2019). 


\section{Conclusion}

Cerebral malaria is one of the most severe and fatal neurological complication with highest mortality. Current therapies in malarial biology are still inadequate in terms of reducing mortality or post-treatment symptoms such as neuro-cognitive deficits. Developments and knowledge on pathophysiology of CM is still not at par, and needs further endeavors to understand the complexity of the disease. Additional perceptions on post complications of CM, with variety of targets need to be exploited for better therapeutic outcomes, specifically against psychosocial trauma. This can only be achieved by improving the management of $\mathrm{CM}$ and understanding the social stigmatic effects of $\mathrm{CM}$ within the community Furthermore, advance investigation is required regarding host-parasite relationship, parasite adhesive factors and host endothelial cell receptors can improve our current knowledge on pathogenesis of CM. Much effort is still required to understand the pathophysiology of CM from cellular to molecular level. This will empower us in improving and producing more effective therapies, designed for both eradicating parasites and treating the aftermath secondary impacts as well.

\section{REFERENCES}

Ahmed M.A., Cox-Singh J. 2015: Plasmodium knowlesi - an emerging pathogen. ISBT Sci. Ser. 10: 134-140.

Alavi Y., Jumbe V., Hartley S., Smith S., Lamping D., Muhit M., Masiye F., Lavy C. 2012: Indignity, exclusion, pain and hunger: the impact of musculoskeletal impairments in the lives of children in Malawi. Disabil. Rehabil. 34: 1736-1746.

Aleem M.A. 2005: Epilepsy in malaria. Epilepsia 46: 601; author reply $601-602$.

Amante F.H., Haque A., Stanley A.C., Rivera Fde L., Randall L.M., Wilson Y.A., Yeo G., Pieper C., Crabb B.S., de Koning-Ward T.F., Lundie R.J., Good M.F., Pinzon-Charry A., Pearson M.S., Duke M.G., McManus D.P., Loukas A., Hill G.R., Engwerda C.R. 2010: Immune-mediated mechanisms of parasite tissue sequestration during experimental cerebral malaria. J. Immunol. 185: 3632-3642.

Ancelin M.L., Calas M., Vidal-Sailhan V., Herbute S., Ringwald P., Vial H.J. 2003: Potent inhibitors of Plasmodium phospholipid metabolism with a broad spectrum of in vitro antimalarial activities. Antimicrob. Agents Chemother. 47: $2590-2597$.

Apinjoh T.O., Ouattara A., Titanji V.P.K., Dummde A., Амambua-NGwa A. 2019: Genetic diversity and drug resistance surveillance of Plasmodium falciparum for malaria elimination: is there an ideal tool for resource-limited sub-Saharan Africa? Malar. J. 18: 217.

Apoorv T.S., BABU P.P. 2016: Minocycline prevents cerebral malaria, confers neuroprotection and increases survivability of mice during Plasmodium berghei ANKA infection. Cytokine 90: $113-123$

Autino B., Corbett Y., Castelli F., Taramelli D. 2012: Pathogenesis of malaria in tissues and blood. Mediterr. J. Hematol. Infect. Dis. 4: e2012061.

Azad C.S., Saxena M., Siddiqui A.J., Bhardwaj J., Puri S.K., Dutta G.P., Anand N., Saxena A.K. 2017: Synthesis of primaquine glyco-conjugates as potential tissue schizontocidal antimalarial agents. Chem. Biol. Drug. Des. 90: 254-261.

Baird J.K., Masbar S., Basri H., Tirtokusumo S., Subianto B., Hoffman S.L. 1998: Age-dependent susceptibility to severe disease with primary exposure to Plasmodium falciparum. J. Infect. Dis. 178: 592-595.

Bakmiwewa S.M., Weiser S., Grey M., Heng B., Guillemin G.J., Ball H.J., Hunt N.H. 2015: Synergistic induction of CXCL10 by interferon-gamma and lymphotoxin-alpha in astrocytes: possible role in cerebral malaria. Cytokine 78: 79-86.

Baptista F.G., Pamplona A., Pena A.C., Mota M.M., Pied S., Vigario A.M. 2010: Accumulation of Plasmodium berghei-infected red blood cells in the brain is crucial for the development of cerebral malaria in mice. Infect. Immun. 78: 4033-4039.

Baragana B., Hallyburton I., Lee M.C., Norcross N.R., Grimaldi R., Otto T.D., Рroto W.R., Blagborough A.M., Meister S., Wirjanata G., Ruecker A., Upton L.M., Abraham T.S., Almeida M.J., Pradhan A., Porzelle A.,
Luksch T., Martinez M.S., Bolscher J.M., Woodland A., Norval S., Zuccotto F., Thomas J., Simeons F., StoJanovski L., Osuna-Cabello M., Brock P.M., Churcher T.S., Sala K.A., Zakutansky S.E., Jimenez-Diaz M.B., Sanz L.M., Riley J., Basak R., Campbell M., Avery V.M., Sauerwein R.W., Dechering K.J., Noviyanti R., Campo B., Frearson J.A., Angulo-Barturen I., Ferrer-Bazaga S., Gamo F.J., Wyatt P.G., Leroy D., Siegl P., Delves M.J., Kyle D.E., Wittlin S., Marfurt J., Price R.N., Sinden R.E., Winzeler E.A., Charman S.A., Bebrevska L., Gray D.W., Campbell S., Fairlamb A.H., Willis P.A., Rayner J.C., Fidock D.A., Read K.D., Gilbert I.H. 2015: A novel multiple-stage antimalarial agent that inhibits protein synthesis. Nature 522: 315-320.

Beare N.A., Lewallen S., Taylor T.E., Molyneux M.E. 2011: Redefining cerebral malaria by including malaria retinopathy. Future Microbiol. 6: 349-355.

Beare N.A., Southern C., Chalira C., Taylor T.E., MolyNeUx M.E., Harding S.P. 2004: Prognostic significance and course of retinopathy in children with severe malaria. Arch. Ophthalmol. 122: 1141-1147.

Beare N.A., Taylor T.E., Harding S.P., Lewallen S., MolYNEUX M.E. 2006: Malarial retinopathy: a newly established diagnostic sign in severe malaria. Am. J. Trop. Med. Hyg. 75: 790-797.

Bhardwaj J., Siddiqui A.J., Goyal M., Prakash K., Soni A., PURI S.K. 2016: Repetitive live sporozoites inoculation under arteether chemoprophylaxis confers protection against subsequent sporozoite challenge in rodent malaria model. Acta Trop. 158: $130-138$.

Bhardwaj J., Siddiqui A.J., Goyal M., Prakash K., Soni A., Puri S.K., Srivastava M. 2015: Host immune response is severely compromised during lethal Plasmodium vinckei infection. Parasitol. Res. 114: 3445-3457.

Boivin M.J., Bangirana P., Byarugaba J., Opoka R.O., Idro R., Jurek A.M., John C.C. 2007: Cognitive impairment after cerebral malaria in children: a prospective study. Pediatrics 119: e360-366.

Brejt J.A., Golightly L.M. 2019: Severe malaria: update on pathophysiology and treatment. Curr. Opin. Infect. Dis. 32: 413-418.

BRUNeEL F. 2019: Human cerebral malaria: 2019 mini review. Rev. Neurol. (Paris) 175: 445-450.

Burgess S.J., Kelly J.X., Shomloo S., Wittlin S., Brun R., Liebmann K., Peyton D.H. 2010: Synthesis, structure-activity relationship, and mode-of-action studies of antimalarial reversed chloroquine compounds. J. Med. Chem. 53: 6477-6489.

Burkey M.D., Murray S.M., Bangirana P., Familiar I., OpoKa R.O., NAKasujJa N., Boivin M., Bass J.K. 2015: Executive function and attention-deficit/hyperactivity disorder in Ugandan children with perinatal HIV exposure. Glob. Ment. Health (Camb) 2: e4. 
Bushell E., Gomes A.R., Sanderson T., Anar B., Girling G., Herd C., Metcalf T., Modrzynska K., Schwach F., Martin R.E., Mather M.W., McFadden G.I., Parts L., Rutledge G.G., Vaidya A.B., Wengelnik K., Rayner J.C., BILlker O. 2017: Functional profiling of a Plasmodium genome reveals an abundance of essential genes. Cell 170: 260-272 e268.

Carter J.A., Lees J.A., Gona J.K., Murira G., Rimba K., NevILLE B.G., Newton C.R. 2006: Severe falciparum malaria and acquired childhood language disorder. Dev Med Child Neurol 48: $51-57$.

Carter J.A., Mung'ala-Odera V., Neville B.G., Murira G., Mturi N., Musumba C., Newton C.R. 2005a: Persistent neurocognitive impairments associated with severe falciparum malaria in Kenyan children. J. Neurol. Neurosurg. Psychiatry 76: 476-481.

Carter J.A., Ross A.J., Neville B.G., Obiero E., Katana K., Mung'ala-Odera V., Lees J.A., Newton C.R. 2005b: Developmental impairments following severe falciparum malaria in children. Trop. Med. Int. Health 10: 3-10.

Chakravorty S.J., Craig A. 2005: The role of ICAM-1 in Plasmodium falciparum cytoadherence. Eur. J. Cell. Biol. 84: 15-27.

Chatterjee A.K., Yeung B.K. 2012: Back to the future: lessons learned in modern target-based and whole-cell lead optimization of antimalarials. Curr. Top. Med. Chem. 12: 473-483.

Chitnis N., Pemberton-Ross P., Yukich J., Hamainza B., Miller J., Reiker T., Eisele T.P., Smith T.A. 2019: Theory of reactive interventions in the elimination and control of malaria. Malar. J. 18: 266.

Claser C., Malleret B., Gun S.Y., Wong A.Y., Chang Z.W., Teo P., See P.C., Howland S.W., Ginhoux F., Renia L. 2011: CD8+ T cells and IFN-gamma mediate the time-dependent accumulation of infected red blood cells in deep organs during experimental cerebral malaria. PLoS ONE 6: e18720.

Coteron J.M., Marco M., Esquivias J., Deng X., White K.L., White J., Koltun M., El Mazouni F., Kokkonda S., Katneni K., Bhamidipati R., Shackleford D.M., Angulo-Barturen I., Ferrer S.B., Jimenez-Diaz M.B., Gamo F.J., Goldsmith E.J., Charman W.N., Bathurst I., Floyd D., Matthews D., Burrows J.N., Rathod P.K., Charman S.A., Phillips M.A. 2011: Structure-guided lead optimization of triazolopyrimidine-ring substituents identifies potent Plasmodium falciparum dihydroorotate dehydrogenase inhibitors with clinical candidate potential. J. Med. Chem. 54: 5540-5561.

Cowman A.F., Healer J., Marapana D., Marsh K. 2016: Malaria: biology and disease. Cell 167: 610-624.

Crabb B.S., Beeson J.G., Amino R., Menard R., Waters A., Winzeler E.A., Wahlgren M., Fidock D.A., Nwaka S. 2012: Perspectives: the missing pieces. Nature 484: S22-23.

Craig A., Scherf A. 2001: Molecules on the surface of the Plasmodium falciparum infected erythrocyte and their role in malaria pathogenesis and immune evasion. Mol. Biochem. Parasitol. 115: 129-143.

Crawley J., Smith S., Kirkham F., Muthinji P., Waruiru C., MARSh K. 1996: Seizures and status epilepticus in childhood cerebral malaria. QJM 89: 591-597.

Crompton P.D., Moebius J., Portugal S., Waisberg M., Hart G., Garver L.S., Miller L.H., Barillas-Mury C., Pierce S.K. 2014: Malaria immunity in man and mosquito: insights into unsolved mysteries of a deadly infectious disease. Annu. Rev. Immunol. 32: 157-187.

Cunnington A.J., Walther M., Riley E.M. 2013: Piecing together the puzzle of severe malaria. Sci. Transl. Med. 5: 211ps218.

Dai M., Freeman B., Shikani H.J., Bruno F.P., Collado J.E., Macias R., Reznik S.E., Davies P., Spray D.C., Tanowitz H.B., Weiss L.M., Desruisseaux M.S. 2012: Altered regulation of Akt signaling with murine cerebral malaria, effects on long-term neuro-cognitive function, restoration with lithium treatment. PLoS ONE 7: e44117.

Daroff R.B. 2001: Cerebral malaria. J. Neurol. Neurosurg. Psychiatry 70: $817-818$.
Dayananda K.K., Achur R.N., Gowda D.C. 2018: Epidemiology, drug resistance, and pathophysiology of Plasmodium vivax malaria. J. Vector Borne Dis. 55: 1-8.

de Miranda A.S., Brant F., Vieira L.B., Rocha N.P., VieiRa E.L.M., Rezende G.H.S., De Oliveira Pimentel P.M., Moraes M.F.D., Ribeiro F.M., Ransohoff R.M., Teixeira M.M., Machado F.S., Rachid M.A., Teixeira A.L. 2016: A neuroprotective effect of the glutamate receptor antagonist MK801 on long-term cognitive and behavioral outcomes secondary to experimental cerebral malaria. Mol. Neurobiol. 54: 7063-7082.

de Miranda A.S., Lacerda-Queiroz N., de Carvalho Vilela M., Rodrigues D.H., Rachid M.A., Quevedo J., Teixeira A.L. 2011: Anxiety-like behavior and proinflammatory cytokine levels in the brain of C57BL/6 mice infected with Plasmodium berghei (strain ANKA). Neurosci. Lett. 491: 202-206.

Dechy-Cabaret O., Benoit-Vical F. 2012: Effects of antimalarial molecules on the gametocyte stage of Plasmodium falciparum: the debate. J. Med. Chem. 55: 10328-10344.

DeWeERd S. 2012: Vaccines: the take-home lesson. Nature 484: S24-25.

Dollat M., Talla C., Sokhna C., Diene Sarr F., Trape J.F., RICHARD V. 2019: Measuring malaria morbidity in an area of seasonal transmission: pyrogenic parasitemia thresholds based on a 20-year follow-up study. PLoS ONE 14: e0217903.

Dondorp A.M., Ince C., Charunwatthana P., Hanson J., van Kuijen A., Faiz M.A., Rahman M.R., Hasan M., Bin Yunus E., Ghose A., Ruangveerayut R., LimmathurotSakul D., Mathura K., White N.J., Day N.P. 2008b: Direct in vivo assessment of microcirculatory dysfunction in severe falciparum malaria. J. Infect. Dis. 197: 79-84.

Dondorp A.M., Lee S.J., Faiz M.A., Mishra S., Price R., Tutra E., Than M., Htut Y., Mohanty S., Yunus E.B., Rahman R., Nosten F., Anstey N.M., Day N.P., White N.J. 2008a: The relationship between age and the manifestations of and mortality associated with severe malaria. Clin. Infect. Dis. 47: $151-157$

Dugbartey A.T., Dugbartey M.T., Apedo M.Y. 1998: Delayed neuropsychiatric effects of malaria in Ghana. J. Nerv. Ment. Dis. 186: $183-186$.

EISENSTEIN M. 2012: Drug development: holding out for reinforcements. Nature 484: S16-18.

Engwerda C., Belnoue E., Gruner A.C., Renia L. 2005: Experimental models of cerebral malaria. Curr. Top. Microbiol. Immunol. 297: 103-143.

Franke-Fayard B., Janse C.J., Cunha-Rodrigues M., RameSar J., Buscher P., Que I., Lowik C., Voshol P.J., den Boer M.A., van Duinen S.G., Febbraio M., Mota M.M., Waters A.P. 2005: Murine malaria parasite sequestration: CD36 is the major receptor, but cerebral pathology is unlinked to sequestration. Proc. Natl. Acad. Sci. U.S.A. 102: 11468-11473.

Frevert U., Nacer A. 2014: Fatal cerebral malaria: a venous efflux problem. Front. Cell. Infect. Microbiol. 4: 155.

Ghazanfari N., Mueller S.N., Heath W.R. 2018: Cerebral malaria in mouse and man. Front. Immunol. 9: 2016.

Hameed P.S., Solapure S., Patil V., Henrich P.P., Magistrado P.A., Bharath S., Murugan K., Vismanath P., Puttur J., Srivastava A., Bellale E., Panduga V., Shanbag G., Awasthy D., Landge S., Morayya S., Koushik K., Saralaya R., Raichurkar A., Rautela N., Roy Choudhury N., Ambady A., Nandishaiah R., Reddy J., Prabhakar K.R., Menasinakai S., Rudrapatna S., Chatterji M., Jimenez-Diaz M.B., Martinez M.S., Sanz L.M., Coburn-Flynn O., Fidock D.A., Lukens A.K., Wirth D.F., Bandodkar B., Mukherjee K., McLaughlin R.E., Waterson D., Rosenbrier-Ribeiro L., Hickling K., Balasubramanian V., Warner P., Hosagrahara V., Dudley A., Iyer P.S., Narayanan S., Kavanagh S., Sambandamurthy V.K. 2015: Triaminopyrimidine is a fast-killing and long-acting antimalarial clinical candidate. Nat. Commun. 6: 6715 
Hawkes M., Elphinstone R.E., Conroy A.L., Kain K.C. 2013 Contrasting pediatric and adult cerebral malaria: the role of the endothelial barrier. Virulence 4: 543-555.

Haynes R.K., Fugmann B., Stetter J., Rieckmann K., Heilmann H.D., Chan H.W., Cheung M.K., Lam W.L., Wong H.N., Croft S.L., Vivas L., Rattray L., Stewart L., Peters W., Robinson B.L., Edstein M.D., Kotecka B., Kyle D.E., Beckermann B., Gerisch M., Radtke M., Schmuck G., Steinke W., Wollborn U., Schmeer K., Romer A. 2006: Artemisone-a highly active antimalarial drug of the artemisinin class. Angew. Chem. Int. Ed. Engl. 45: 2082-2088.

Hearn J., Rayment N., Landon D.N., Katz D.R., de Souza J.B. 2000: Immunopathology of cerebral malaria: morphological evidence of parasite sequestration in murine brain microvasculature. Infect. Immun. 68: 5364-5376.

Heyes M.P., Saito K., Major E.O., Milstien S., Markey S.P., Vickers J.H. 1993: A mechanism of quinolinic acid formation by brain in inflammatory neurological disease. Attenuation of synthesis from L-tryptophan by 6-chlorotryptophan and 4-chloro-3-hydroxyanthranilate. Brain 116: 1425-1450.

Hien T.T., White N.J., Thuy-Nhien N.T., Hoa N.T., Thuan P.D., Tarning J., Nosten F., Magnusson B., Jain J.P., Hamed K. 2017: Estimation of the in vivo MIC of cipargamin in uncomplicated Plasmodium falciparum malaria. Antimicrob. Agents Chemother. 61: e01940-16.

Holding P.A., Stevenson J., Peshu N., Marsh K. 1999: Cognitive sequelae of severe malaria with impaired consciousness. Trans. R. Soc. Trop. Med. Hyg. 93: 529-534.

Hunt N.H., Grau G.E., Engwerda C., Barnum S.R., van der Heyde H., Hansen D.S., Schofield L., Golenser J. 2010: Murine cerebral malaria: the whole story. Trends Parasitol. 26 272-274.

Idro R., Carter J.A., Fegan G., Neville B.G., Newton C.R. 2006: Risk factors for persisting neurological and cognitive impairments following cerebral malaria. Arch. Dis. Child. 91: $142-148$.

Idro R., Jenkins N.E., Newton C.R. 2005: Pathogenesis, clinical features, and neurological outcome of cerebral malaria. Lancet Neurol. 4: 827-840.

Idro R., Kakooza-Mwesige A., Asea B., Ssebyala K., Bangirana P., Opoka R.O., Lubowa S.K., Semrud-Clikeman M., John C.C., Nalugya J. 2016: Cerebral malaria is associated with long-term mental health disorders: a cross sectional survey of a long-term cohort. Malar. J. 15: 184.

Idro R., Kakooza-Mwesige A., Balyejuussa S., Mirembe G., Mugasha C., Tugumisirize J., Byarugaba J. 2010a: Severe neurological sequelae and behaviour problems after cerebral malaria in Ugandan children. BMC Res. Notes. 3: 104.

Idro R., Marsh K., John C.C., Newton C.R. 2010b: Cerebral malaria: mechanisms of brain injury and strategies for improved neurocognitive outcome. Pediatr. Res. 68: 267-274.

John C.C., Bangirana P., Byarugaba J., Opoka R.O., Idro R., Jurek A.M., Wu B., Boivin M.J. 2008: Cerebral malaria in children is associated with long-term cognitive impairment. Pediatrics 122: e92-99.

Jones C.O., Williams H.A. 2004: The social burden of malaria: what are we measuring? Am. J. Trop. Med. Hyg. 71: 156-161.

Kerlin D.H., Gatton M.L. 2013: Preferential invasion by Plasmodium merozoites and the self-regulation of parasite burden. PLoS ONE 8: e57434.

Kraemer S.M., Smith J.D. 2006: A family affair: var genes, PfEMP1 binding, and malaria disease. Curr. Opin. Microbiol. 9: $374-380$.

Lacerda-Queiroz N., Rodrigues D.H., Vilela M.C., Miranda A.S., Amaral D.C., Camargos E.R., Carvalho L.J., Howe C.L., Teixeira M.M., Teixeira A.L. 2010: Inflammatory changes in the central nervous system are associated with behavioral impairment in Plasmodium berghei (strain ANKA)-infected mice. Exp. Parasitol. 125: 271-278.
Lackner P., Beer R., Heussler V., Goebel G., Rudzki D., Helbok R., Tannich E., Schmutzhard E. 2006: Behavioural and histopathological alterations in mice with cerebral malaria. Neuropathol. Appl. Neurobiol. 32: 177-188.

Lewallen S., Bronzan R.N., Beare N.A., Harding S.P., MolyneuX M.E., TAYlor T.E. 2008: Using malarial retinopathy to improve the classification of children with cerebral malaria. Trans. R. Soc. Trop. Med. Hyg. 102: 1089-1094.

Lou H.C., Henriksen L., Bruhn P., Borner H., Nielsen J.B. 1989: Striatal dysfunction in attention deficit and hyperkinetic disorder. Arch. Neurol. 46: 48-52.

Luzolo A.L., NGoyi D.M. 2019: Cerebral malaria. Brain Res. Bull. 145: 53-58

MacPherson G.G., Warrell M.J., White N.J., LooareesuWAN S., WARrell D.A. 1985: Human cerebral malaria. A quantitative ultrastructural analysis of parasitized erythrocyte sequestration. Am. J. Pathol. 119: 385-401.

Marcsisin S.R., Sousa J.C., Reichard G.A., Caridha D., Zeng Q., Roncal N., McNulty R., Careagabarja J., Sciotti R.J., Bennett J.W., Zottig V.E., Deye G., Li Q., Read L., Hickman M., Dhammika Nanayakkara N.P., Walker L.A., Smith B., Melendez V., Pybus B.S. 2014: Tafenoquine and NPC-1161B require CYP 2D metabolism for anti-malarial activity: implications for the 8-aminoquinoline class of anti-malarial compounds. Malar. J. 13: 2.

Marsh K., Forster D., Waruiru C., Mwangi I., Winstanley M., Marsh V., Newton C., Winstanley P., Warn P., Peshu N., ET AL. 1995: Indicators of life-threatening malaria in African children. N Engl J Med 332: 1399-1404.

Mbale E.W., Taylor T., Brabin B., Mallewa M., Gladstone M. 2017: Exploring neurodevelopmental outcome measures used in children with cerebral malaria: the perspectives of caregivers and health workers in Malawi. BMC Pediatr. 17: 9.

Medana I.M., Day N.P., Hien T.T., White N.J., Turner G.D. 2009: Erythropoietin and its receptors in the brainstem of adults with fatal falciparum malaria. Malar. J. 8: 261.

Meldrum B.S. 2000: Glutamate as a neurotransmitter in the brain: review of physiology and pathology. J. Nutr. 130: 1007S-1015S.

Miranda A.S., Vieira L.B., Lacerda-Queiroz N., Souza A.H., Rodrigues D.H., Vilela M.C., Gomez M.V., MachaDo F.S., Rachid M.A., Teixeira A.L. 2010: Increased levels of glutamate in the central nervous system are associated with behavioral symptoms in experimental malaria. Braz. J. Med. Biol. Res. 43: 1173-1177.

Moxon C.A., Wassmer S.C., Milner D.A., JR., Chisala N.V., Taylor T.E., Seydel K.B., Molyneux M.E., Faragher B., Esmon C.T., Downey C., Toh C.H., Craig A.G., HeyderMAN R.S. 2013: Loss of endothelial protein C receptors links coagulation and inflammation to parasite sequestration in cerebral malaria in African children. Blood 122: 842-851.

Nakamura T.A., Yamada K., Hasegawa T., Nabeshima T. 1995: Possible involvement of nitric oxide in quinolinic acid-induced convulsion in mice. Pharmacol. Biochem. Behav. 51: 309-312.

Nelson F., Masulani-Mwale C., Richards E., Theobald S., Gladstone M. 2017: The meaning of participation for children in Malawi: insights from children and caregivers. Child Care Health Dev. 43: 133-143.

Newbold C., Warn P., Black G., Berendt A., Craig A., Snow B., Msobo M., Peshu N., Marsh K. 1997: Receptor-specific adhesion and clinical disease in Plasmodium falciparum. Am. J. Trop. Med. Hyg. 57: 389-398.

Newton C.R., Crawley J., Sowumni A., Waruiru C., Mwangi I., English M., Murphy S., Winstanley P.A., Marsh K., KIRKHAM F.J. 1997: Intracranial hypertension in Africans with cerebral malaria. Arch. Dis. Child 76: 219-226.

Newton C.R., Krishna S. 1998: Severe falciparum malaria in children: current understanding of pathophysiology and supportive treatment. Pharmacol. Ther. 79: 1-53. 
Ngoungou E.B., Dulac O., Poudiougou B., Druet-Cabanad M., Dicko A., Mamadou Traore A., Coulibaly D., Farnarier G., Tuillas M., Keita M.M., Kombila M., Doumbo O.K., Preux P.M. 2006: Epilepsy as a consequence of cerebral malaria in area in which malaria is endemic in Mali, West Africa. Epilepsia 47: 873-879.

Nguyen T.H., Day N.P., Ly V.C., Waller D., Mai N.T., Bethell D.B., Tran T.H., White N.J. 1996: Post-malaria neurological syndrome. Lancet 348: 917-921.

Nishanth G., Schluter D. 2019: Blood-brain barrier in cerebral malaria: pathogenesis and therapeutic intervention. Trends Parasitol. 35: 516-528.

Oliveira K., Kauffmann N., Leao L.K.R., Passos A.C.F., Rocha F.A.F., Herculano A.M., do Nascimento J.L.M. 2017: Cerebral malaria induces electrophysiological and neurochemical impairment in mice retinal tissue: possible effect on glutathione and glutamatergic system. Malar. J. 16: 440.

Patel M., Sachidanandan M., Adnan M. 2019: Serine arginine protein kinase 1 (SRPK1): a moonlighting protein with theranostic ability in cancer prevention. Mol. Biol. Rep. 46: 1487-1497.

Perkins D.J., Were T., Davenport G.C., Kempaiah P., HitTNER J.B., ONG'EChA J.M. 2011: Severe malarial anemia: innate immunity and pathogenesis. Int. J. Biol. Sci. 7: 1427-1442.

Pongponratn E., Riganti M., Punpoowong B., Aikawa M. 1991: Microvascular sequestration of parasitized erythrocytes in human falciparum malaria: a pathological study. Am. J. Trop. Med. Hyg. 44: 168-175.

Pongronratn E., Turner G.D., Day N.P., Phu N.H., Simpson J.A., Stepniewska K., Mai N.T., Viriyavejakul P., Looareesuman S., Hien T.T., Ferguson D.J., White N.J. 2003: An ultrastructural study of the brain in fatal Plasmodium falciparum malaria. Am. J. Trop. Med. Hyg. 69: 345-359.

Ponsford M.J., Medana I.M., Prapansilp P., Hien T.T., Lee S.J., Dondorp A.M., Esiri M.M., Day N.P., White N.J., TURNer G.D. 2011: Sequestration and microvascular congestion are associated with coma in human cerebral malaria. J. Infect. Dis. 205: 663-671.

Postels D.G., Birbeck G.L. 2013: Cerebral malaria. Handb. Clin. Neurol. 114: 91-102.

Powles M.A., Allocco J., Yeung L., Nare B., Liberator P., Schmatz D. 2012: MK-4815, a potential new oral agent for treatment of malaria. Antimicrob. Agents Chemother. 56: 2414-2419.

Prakash K., Goyal M., Soni A., Siddiqui A.J., Bhardwa J., PURI S.K. 2014: Molecular cloning and biochemical characterization of iron superoxide dismutase from the rodent malaria parasite Plasmodium vinckei. Parasitol. Int. 63: 817-825.

Prudencio M., Rodriguez A., Mota M.M. 2006: The silent path to thousands of merozoites: the Plasmodium liver stage. Nat. Rev. Microbiol. 4: 849-856.

Reiner R.C., JR., Olsen H.E., Ikeda C.T., Echko M.M., Ballestreros K.E., Manguerra H., Martopullo I., Millear A., Shields C., Smith A., Strub B., Abebe M., Abebe Z., Adhena B.M., Adhikari T.B., Akibu M., Al-RaddaDi R.M., Alvis-Guzman N., Antonio C.A.T., Aremu O., Asgedom S.W., Asseffa N.A., Avila-Burgos L., Barac A., Barnighausen T.W., Bassat Q., Bensenor I.M., Bhutta Z.A., Bijani A., Bililign N., Cahuana-Hurtado L., Malta D.C., Chang J.C., Charlson F.J., Dharmaratne S.D., Doku D.T., Edessa D., El-Khatib Z., Erskine H.E., Ferrari A.J., Fullman N., Gupta R., Hassen H.Y., Hay S.I., Ilesanmi O.S., Jacobsen K.H., Kahsay A., Kasaeian A., Kassa T.D., Kebede S., Khader Y.S., Khan E.A., Khan M.N., Khang Y.H., Khubchandani J., Kinfu Y., Kochhar S., Kokubo Y., Koyanagi A., Defo B.K., Lal D.K., Kumsa F.A., Larson H.J., Leung J., Mamun A.A., Mehata S., Melku M., Mendoza W., Mezgebe H.B., Miller T.R., Moges N.A., Mohammed S., Mokdad A.H., Monasta L., Neupane S., NGuyen H.L.T., Ningrum D.N.A., Nirayo Y.L., Nong V.M., Ogbo F.A., Olagunue A.T., Olusanya B.O.,
Olusanya J.O., Patton G.C., Pereira D.M., Pourmalek F., Qorbani M., Rafay A., Rai R.K., Ram U., Ranabhat C.L., Renzaho A.M.N., Rezai M.S., Ronfani L., Roth G.A., SAfiri S., Sartorius B., Scott J.G., Shackelford K.A., Sliwa K., Sreeramareddy C., Sufiyan M.B., Terkawi A.S., Topor-Madry R., Tran B.X., Ukwaja K.N., Uthman O.A., Vollset S.E., Weldegwergs K.G., Werdecker A., Whiteford H.A., Wijeratne T., Yonemoto N., Yotebieng M., Zuhlke L.J., Kyu H.H., Naghavi M., Vos T., Murray C. J.L., Kassebaum N.J. 2019: Diseases, injuries, and risk factors in child and adolescent health, 1990 to 2017: findings from the global burden of diseases, injuries, and risk factors 2017 study. JAMA Pediatr. 173: e190337.

Riggle B.A., Miller L.H., Pierce S.K. 2020: Desperately seeking therapies for cerebral malaria. J. Immunol. 204: 327-334.

Roggero R., Zufferey R., Minca M., Richier E., Calas M., Vial H., Ben Mamoun C. 2004: Unraveling the mode of action of the antimalarial choline analog G25 in Plasmodium falciparum and Saccharomyces cerevisiae. Antimicrob. Agents Chemother. 48: 2816-2824.

Sahu P.K., Satpathi S., Behera P.K., Mishra S.K., Mohanty S., Wassmer S.C. 2015: Pathogenesis of cerebral malaria: new diagnostic tools, biomarkers, and therapeutic approaches. Front. Cell. Infect. Microbiol. 5: 75.

Samby K., Ramachandruni H., Banerji J., Burrows J.N., Daumerie P.G., Hooft van Huijsduijnen R.A.M., Duparc S., Wells T.N.C. 2019: Partnering to fight malaria in India: past, present and future. J. Vector Borne Dis. 56: 15-24.

Schantz-Dunn J., Nour N.M. 2009: Malaria and pregnancy: a global health perspective. Rev. Obstet. Gynecol. 2: 186-192.

Schumacher R.F., Spinelli E. 2012: Malaria in children. Mediterr. J. Hematol. Infect. Dis. 4: e2012073.

Scott J.A., Berkley J.A., Mwangi I., Ochola L., Uyoga S., Macharia A., Ndila C., Lowe B.S., Mwarumba S., Bauni E., Marsh K., Williams T.N. 2011: Relation between falciparum malaria and bacteraemia in Kenyan children: a population-based, case-control study and a longitudinal study. Lancet 378: 1316-1323.

Shafiq N., Rajagopalan S., Kushwaha H.N., Mittal N., Chandurkar N., Bhalla A., Kaur S., Pandhi P., Puri G.D., Achuthan S., Pareek A., Singh S.K., Srivastava J.S., Gaur S.P., Malhotra S. 2014: Single ascending dose safety and pharmacokinetics of CDRI-97/78: first-in-human study of a novel antimalarial drug. Malar. Res. Treat. 2014: 372521.

ShetTy P. 2012: The numbers game. Nature 484: S14-15.

Shikani H.J., Freeman B.D., Lisanti M.P., Weiss L.M., Tanowitz H.B., Desruisseaux M.S. 2012: Cerebral malaria: we have come a long way. Am. J. Pathol. 181: 1484-1492.

Siddiqui A.J., Bhardwaj J., Goyal M., Prakash K., Soni A., Tiwari V., PUri S.K. 2015: Assessment of real-time method to detect liver parasite burden under different experimental conditions in mice infected with Plasmodium yoelii sporozoites. Microb. Pathog. 89: 35-42.

Siddiqui A.J., Bhardwaj J., Puri S.K. 2011: mRNA expression of cytokines and its impact on outcomes after infection with lethal and nonlethal Plasmodium vinckei parasites. Parasitol. Res. 110: $1517-1524$.

Siddigui A.J., Molehin A.J., Zhang W., Ganapathy P.K., Kim E., Rojo J.U., Redman W.K., Sennoune S.R., Sudduth J., Freeborn J., Hunter D., Kottapalli K.R., Kottapalli P., Wettahhinghe R., van Dam G.J., Corstjens P., Papin J.F., Carey D., Torben W., Ahmad G., Siddiqui A.A. 2018: Sm-p80-based vaccine trial in baboons: efficacy when mimicking natural conditions of chronic disease, praziquantel therapy, immunization, and Schistosoma mansoni re-encounter. Ann. N. Y. Acad. Sci. 1425: 19-37.

Silamut K., Phu N.H., Whitty C., Turner G.D., Louwrier K., Mai N.T., Simpson J.A., Hien T.T., White N.J. 1999: 
A quantitative analysis of the microvascular sequestration of malaria parasites in the human brain. Am. J. Pathol. 155: 395-410.

Singh A., Yeh C.J., Verma N., Das A.K. 2016: Overview of attention deficit hyperactivity disorder in young children. Health Psychol. Res. 3: 2115.

Sokol D.K., Demyer W.E., Edwards-Brown M., Sanders S., GARG B. 2003: From swelling to sclerosis: acute change in mesial hippocampus after prolonged febrile seizure. Seizure 12: 237-240.

Soni A., Goyal M., Prakash K., Bhardwaj J., Siddiqui A.J., PURI S.K. 2015: Cloning, expression and functional characterization of heme detoxification protein (HDP) from the rodent malaria parasite Plasmodium vinckei. Gene 566: 109-119.

Ssentongo P., Robuccio A.E., Thuku G., Sim D.G., Nabi A., Bahari F., Shanmugasundaram B., Billard M.W., Geronimo A., Short K.W., Drew P.J., Baccon J., WeinStein S.L., Gilliam F.G., Stoute J.A., Chinchilli V.M., Read A.F., Gluckman B.J., Schiff S.J. 2017: A murine model to study epilepsy and SUDEP induced by malaria infection. Sci. Rep. 7: 43652

Stone T.W., Connick J.H., Winn P., Hastings M.H., English M. 1987: Endogenous excitotoxic agents. Ciba Found. Symp. 126: 204-220.

Strangward P., Haley M.J., Shaw T.N., Schwartz J.M., Greig R., Mironov A., de Souza J.B., Cruickshank S.M., Craig A.G., Milner D.A., Jr., Allan S.M., Couper K.N. 2017: A quantitative brain map of experimental cerebral malaria pathology. PLoS Pathog. 13: e1006267.

Stresman G., Bousema T., Cook J. 2019: Malaria hotspots: is there epidemiological evidence for fine-scale spatial targeting of interventions? Trends. Parasitol. 35: 822-834.

Taylor T.E., Fu W.J., Carr R.A., Whitten R.O., Mueller J.S., Fosiko N.G., Lewallen S., Liomba N.G., Molyneux M.E. 2004: Differentiating the pathologies of cerebral malaria by postmortem parasite counts. Nat. Med. 10: 143-145.

Thievent K., Zilio G., Hauser G., Koella J.C. 2019: Malaria load affects the activity of mosquito salivary apyrase. J. Insect. Physiol. 116: 10-16.

Tse E.G., KorsiK M., Todd M.H. 2019: The past, present and future of anti-malarial medicines. Malar. J. 18: 93.

Turner L., Lavstsen T., Berger S.S., Wang C.W., Petersen J.E., Avril M., Brazier A.J., Freeth J., Jespersen J.S., Nielsen M.A., Magistrado P., Lusingu J., Smith J.D., Higgins M.K., Theander T.G. 2013: Severe malaria is associated with parasite binding to endothelial protein $\mathrm{C}$ receptor. Nature 498: 502-505.

Vennerstrom J.L., Arbe-Barnes S., Brun R., Charman S.A., Chiu F.C., Chollet J., Dong Y., Dorn A., Hunziker D., Matile H., Mcintosh K., Padmanilayam M., Santo Tomas J., Scheurer C., Scorneaux B., Tang Y., Urwyler H., Wittlin S., Charman W.N. 2004: Identification of an antimalarial synthetic trioxolane drug development candidate. Nature 430: 900-904

Walker O., Salako L.A., Sowunmi A., Thomas J.O., Sodeine O., Bondi F.S. 1992: Prognostic risk factors and post mortem findings in cerebral malaria in children. Trans. R. Soc. Trop. Med. Hyg. 86: 491-493.
Wassmer S.C., Taylor T.E., Rathod P.K., Mishra S.K., Mohanty S., Arevalo-Herrera M., Duraisingh M.T., Smith J.D. 2015: Investigating the Pathogenesis of Severe Malaria: A Multidisciplinary and Cross-Geographical Approach. Am. J. Trop. Med. Hyg. 93: 42-56.

Wells T.N., Hooft van Huijsduijnen R., Van Voorhis W.C. 2015: Malaria medicines: a glass half full? Nat. Rev. Drug. Discov. 14: 424-442.

White N.J., Pukrittayakamee S., Hien T.T., Faiz M.A., Mokuolu O.A., Dondorp A.M. 2013: Malaria. Lancet 383: 723-735.

WHO 2006: World Malaria Report 2006. World Health Organisation, Geneva.

WHO 2011: World Malaria Report 2011. World Health Organisation, Geneva.

WHO 2015: World Malaria Report 2015. World Health Organisation, Geneva.

WHO 2017: World Malaria Report 2017. World Health Organisation, Geneva.

WHO 2018: World Malaria Report 2018. World Health Organisation, Geneva.

WiJdicks E.F.M., PARK J.G. 2018: Surviving cerebral malaria. Neurology 91: 978-979.

Wilson K.D., Stutz S.J., Ochoa L.F., Valbuena G.A., Cravens P.D., Dineley K.T., Vargas G., Stephens R. 2016: Behavioural and neurological symptoms accompanied by cellular neuroinflammation in IL-10-deficient mice infected with Plasmodium chabaudi. Malar. J. 15: 428.

Win Han O., Gold L., Moore K., Agius P.A., Fowkes F.J.I. 2019: The impact of community-delivered models of malaria control and elimination: a systematic review. Malar. J. 18: 269.

Yadav D.K., Kumar S., Teli M.K., Yadav R., Chaudhary S. 2019: Molecular targets for malarial chemotherapy: a review. Curr. Top. Med. Chem. 19: 861-873.

Yuthavong Y., Tarnchompoo B., Vilaivan T., Chitnumsub P., Kamchonwongpaisan S., Charman S.A., McLennan D.N., White K.L., Vivas L., Bongard E., ThongphanChang C., Taweechai S., Vanichtanankul J., Rattanajak R., Arwon U., Fantauzzi P., Yuvaniyama J., Charman W.N., Matthews D. 2012: Malarial dihydrofolate reductase as a paradigm for drug development against a resistance-compromised target. Proc. Natl. Acad. Sci. U. S. A. 109: 16823-16828.

Zhang W., Ahmad G., Molehin A.J., Torben W., Le L., Kim E., Lazarus S., Siddiqui A.J., Carter D., Siddiqui A.A. 2018a: Schistosoma mansoni antigen Sm-p80: prophylactic efficacy using TLR4 agonist vaccine adjuvant glucopyranosyl lipid A-Alum in murine and non-human primate models. J. Investig. Med. 66: 1124-1132.

Zhang W., Molehin A.J., Rojo J.U., Sudduth J., Ganapathy P.K., Kim E., Siddiqui A.J., Freeborn J., Sennoune S.R., May J., Lazarus S., Nguyen C., Redman W.K., Ahmad G., Torben W., Karmakar S., Le L., Kottapalli K.R., Kottapalli P., Wolf R.F., Papin J.F., Carey D., Gray S.A., Bergthold J.D., Damian R.T., Mayer B.T., Marks F., Reed S.G., Carter D., Siddiqui A.A. 2018b: Sm-p80-based schistosomiasis vaccine: double-blind preclinical trial in baboons demonstrates comprehensive prophylactic and parasite transmission-blocking efficacy. Ann. N. Y. Acad. Sci. 1425: 38-51. 